\title{
Priority Lines of Krasnoyarsk Territory (Krai) Food Market Competitive Status Development
}

\author{
Iurii L. Aleksandrov \\ and Liudmila V. Iushkova* \\ Siberian Federal University \\ 79 Svobodny, Krasnoyarsk, 660041, Russia
}

Received 24.07.2016, received in revised form 16.09.2016, accepted 02.10.2016

The article presents the main lines of development of the competitive status of the Krasnoyarsk Territory (Krai) food market. It demonstrates that competitive status development depends on the achievement of open competitive environment conditions, which provides equal conditions for all players; competitive recovery of the food market and its products; implementation of technological innovations; improvement of the competitive position of the Krasnoyarsk Territory (Krai) food market within the Siberian Federal District and foreign markets. A separate trend of development is associated with the formation of information and communication space as a cohesive force for creating and maintaining the image of the Krasnoyarsk Territory (Krai) food market as a reliable, socially responsible and sustainable business partner.

Keywords: food market, competitive status, competitiveness, competitive position.

DOI: 10.17516/1997-1370-2016-9-11-2853-2862.

Research area: economics.

\section{Introduction}

The position of a food market as a member of the competition process and introduction of such definition as a "competitive status of a food market" into research terminology are based on understanding of the transformation process of indicators, qualities, and parameters underlying the competitiveness of various economic systems, as well as competition results used as investments into the strong sides of service industry and its subjects.

Competitive status of a food market means its stable position among similar economic subjects within a competitive environment, proven by the stability of this economic system's parameters within a certain time interval and its success in the competitive battle. Besides its good positions in the competition rating, but low stability of the competitive position, the research of the competitive status of the Krasnoyarsk Territory (Krai) food market revealed its lagging behind similar subjects of other regions of the SFD. Consequently, improvement of its efficiency as a competitor becomes an acute issue.

The priority tasks for development of the competitive status of the Krasnoyarsk Territory (Krai) food market shall include:

(C) Siberian Federal University. All rights reserved

* Corresponding author E-mail address: yaleksandrov@sfu-kras.ru; kmarketing05@mail.ru 


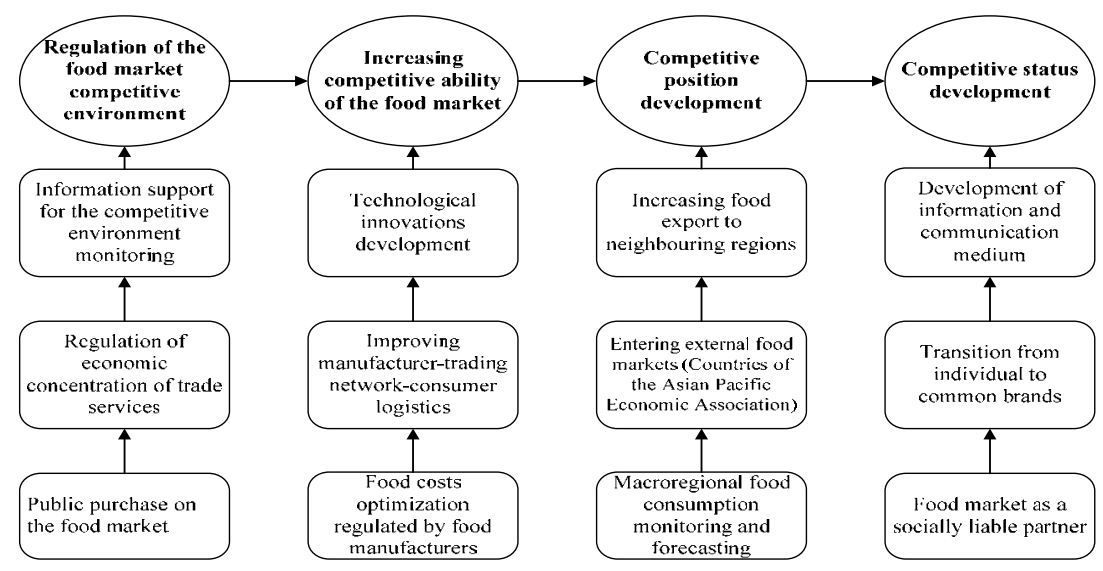

Fig. 1. Priority trends in regulation of the Krasnoyarsk Territory (Krai) food market competitive status

- creation of favourable environment for development of the competitive status of the Krasnoyarsk Territory (Krai) food market (competitive environment);

- achievement of high competitiveness level by the regional food market;

- localization of the food market of the Krasnoyarsk Territory (Krai) within the most favourable and stable competitive position within the SFD microregion;

- guarantee of a trustworthy partner image from the point of view of creating welcoming business climate in the region, territory of well-being, security and comfort for life, and, therefore, provision of a proper competitive status for the Krasnoyarsk Territory (Krai) food market (Fig. 1).

\section{Regulation of the competitive environment development}

To regulate competitive situation on the food market and its competitive environment in particular, it is necessary to focus on the preventive measures aimed at protecting the market from unfair competition, but not setting the task as impeding prosecution on food producing companies. Such measures include:

Improving information support for the competitive environment monitoring by OFAS bodies. The main line of information support development is bringing statistic report forms into compliance with the needs of OFAS analytics and unification of statistic calculation methods. Thus, independent monitoring over changing prices and sales volumes of certain goods carried out by OFAS experts does not comply to "timeliness" and "efficiency" criteria, which may be compensated by the effort of local statistic bodies [5].

Regulation of the economic concentration of trade services. First of all, this measure shall concern the review of "antimonopoly provisions" of the Federal Law No. 381-FZ of December 2009 "Basic state regulation of trading activities in the Russian Federation" (Articles 13-16 of the Federal Law) based on comprehensive discussion of its regulating power by the authorities and social representatives. Regulation of economic concentration of trading services also depends on the optimization of functions and scale of the spheres regulated by the antimonopoly service, which is responsible for solving tasks from economic concentration and competition regulation by the authority bodies to public purchase control, from advertising law enforcement to foreign investments into strategic industrial branches.

\section{Regulation of the food market openness} barrier. Barrier regulation includes two main 
lines: adjustment of height (scope) of entrance and exit barriers for economic agents and protection of food market independence from importers, encouraging local brand export. Current Commodity Market Competition Analysis Instruction suggests considering the intensity of new market members' appearance within a certain time period as an indirect confirmation of presence (absence) of such market entrance barriers, though it does not state that the dynamics of companies' entrance to the market may not serve as an entrance barrier indicator; "impossibility of profitable presence of one more vendor in the market" [2] as such may not indicate the presence of a barrier, determined by difference in economic efficiency of some certain types of business. In this situation, it is reasonable to involve experts from different spheres for barrier monitoring and indication of such barriers in all advanced analytic reports concerning violation of antimonopoly legislation, especially in markets attended by national corporations and foreign companies.

4. Changing the public purchase system currently existing in the food market. Including public purchase into the OFAS jurisdiction increases the number of procurement infrastructure members, thereby decreasing its monopolization, though modern reality reveals the need for regulation by means of: enhancing responsibility for violating food products supply terms or improper goods quality, reviewing the defaulting supplier criteria; increasing control over affiliate behaviour and subsequent creation of a database of companies registered as belonging to different persons but acting as a single business; specification of universal requirements to supplies in different markets of technically complicated goods, services and food products; transition from purchase control to purchase result

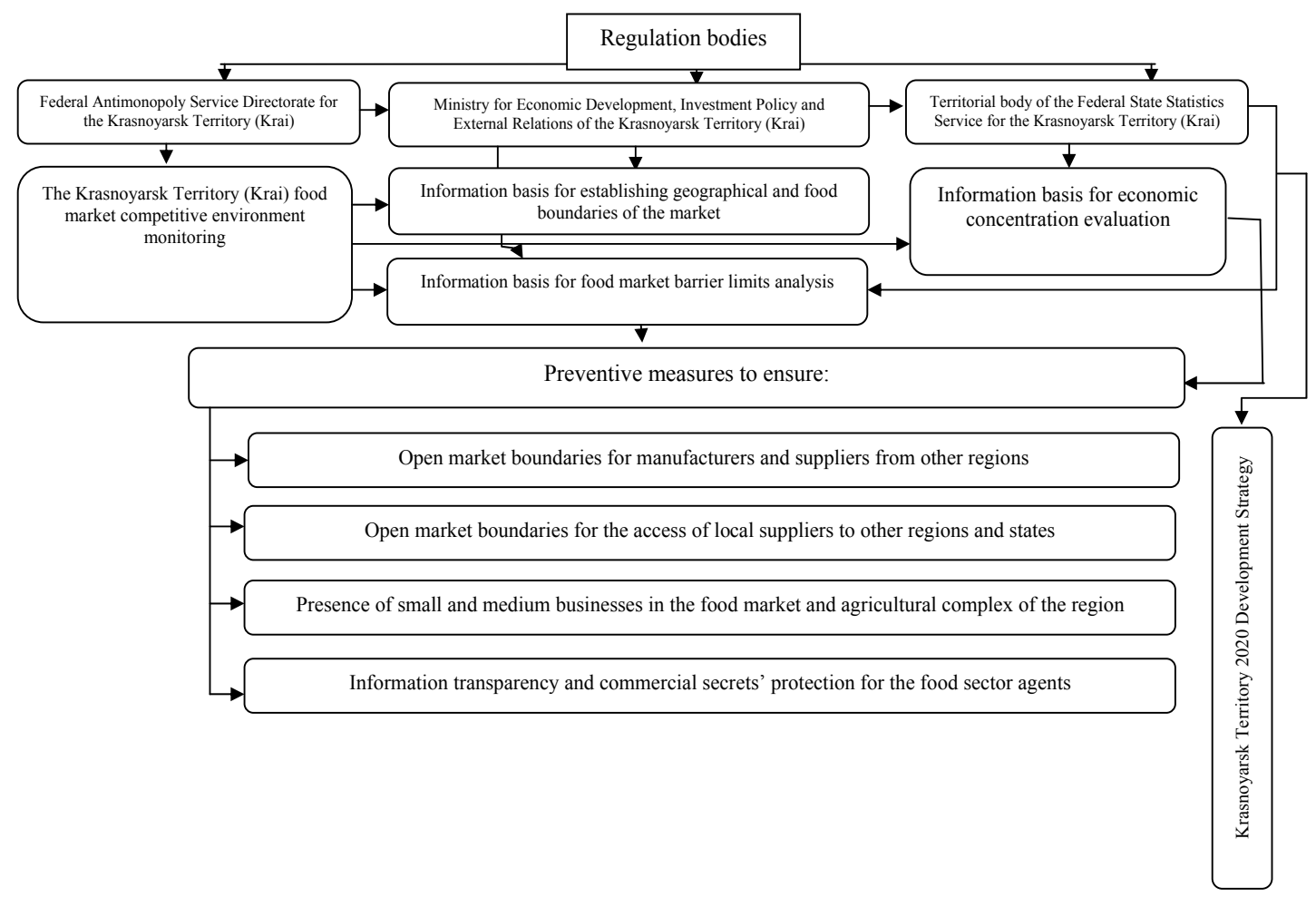

Fig. 2. Process of food market competitive environment regulation for developing its competitive status 
control to eliminate the corruption component in the public purchase system; improvement of legislation and evidence of corruptive activity of the state officials.

The activities described above are united into the food market competitive environment regulation process, determining the creation and development of proper competitive status (Fig. 2).

The suggested preventive measures aimed at regulation of the openness of market boundaries, its information transparency and support of small businesses, completely conform to the Krasnoyarsk Territory (Krai) economy development strategy 2030.

\section{Increasing competitive ability of the food market}

The increase of competitive ability of the food market, targeted at achieving higher efficiency in comparison with that of the neighbouring regions shall be concentrated on:

\section{Development of technological} innovations, serving as a classic competition driver and determining conditions for increasing competitive ability of the food market. Being a sophisticated social and economic system, the food market needs innovations for resolving a large variety of issues: to guarantee economic and physical availability of adequate and healthy nutrition for the population, to coordinate interaction between the agricultural complex and food industries at the stage of startug new manufacturing cycles, to play a controlling role. Another peculiarity of the food market establishing the need for technological innovations is little elasticity of demand for the main food groups with little variability of elasticity within the groups; for this reason to form and support the competitive status, we suggest that the state supports the industry and supplies a greater variety of substitute products by means of reviving national food traditions and increasing competitive ability of different food products by means of using geographically endemic raw materials and wild crops, which are usually quite cheap.

Technological innovations on the food market also concern progressive forms of trading services, where, in our opinion, it is relevant to concentrate on increasing availability of trading facilities, their convenience for buyers, and attenuating the loss of food products during transportation and storage by implementing such trading facilities as vending machines, mobile tents, pavilion cars, farm shops; in some cases, it makes sense to organize delivery and retail delivery trade.

2. Improving food delivery logistics from the manufacturer to the consumer can be done through optimization of product distribution infrastructure in order to decrease the delivery term and costs of food vending services. Shifting the emphasis from competition between manufacturers to competition between suppliers, the main tools for delivery logistics optimization are targeted support with the credit interest rate and the guarantor role of executive authorities for providing certain order of food products from agricultural manufacturers during the transition period. Uneven distribution of income and profit on different levels of product distribution is the limiting power of competition, which, along with the short expiration period of many food products, often stimulates oligopolistic plots of the logistic intermediaries. In this context, regulating activities shall include development of an efficient manufacturing and distributing cluster which would, on one hand, quicken the delivery and, on the other hand, minimize the risks of increasing the economic concentration of the supplier sector.

1. Price control of trading service costs is done through trading margin optimization. 


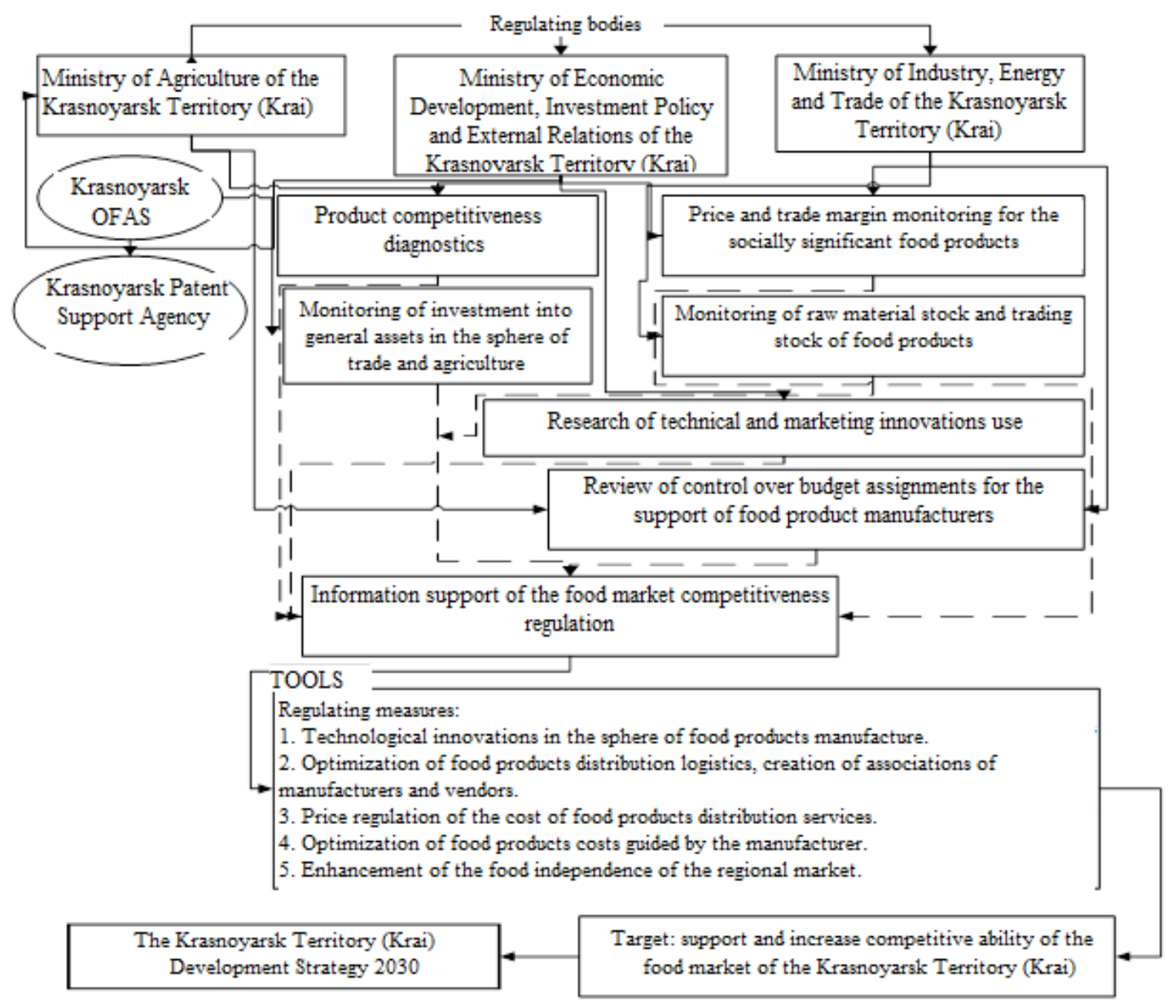

Fig. 3. Process the Krasnoyarsk Territory (Krai) competitive ability regulation for competitive status development

In our opinion, such regulation should include: monitoring of food products in retail distribution networks, closed catering facilities (canteens of schools, colleges, kindergartens, hospitals); organization of purchasing and food product interventions, especially concerning season food products; creation of fixed cost price and retail price corridors for socially significant food products; limitation of packing and branding costs for socially significant food products and supporting food products promotion in local mass media.

2. Food products cost optimization guided by the manufacturer shall be based on: decreasing the costs of trading intermediaries' services and services of various counteragents in the food cost; shifting the product distribution initiative to the manufacturer; protective measures of the regional authorities concerning high-quality certified products; organization of a research and development fund to improve the utilities and facilities of food product manufacturers and selection of agricultural raw materials; stimulation of discount groceries selling food products for comfortable price with minimal margin; providing tax benefits and subsidies to enterprises improving eco-friendly production and increasing competitive ability of food products on the domestic and international markets; solving issues of efficient control 
over the manufactured food products for the companies receiving targeted aid and tax benefits; considering guarantees of inter-company relations for agricultural manufacturers and retail facilities by creating branch associations.

Solution of the Krasnoyarsk Territory (Krai) food market competitive ability issues requires active participation of the corresponding ministries: Ministry of Agriculture on one hand, and Ministry of Industry, Energy and Trade on the other (see Figure 3). In this situation, Ministry of Agriculture shall over the issues of regulating the competitive ability of agricultural products, of food sovereignty of the market, smoothening the season component of creating the food stock on the market, while the Ministry of Industry shall take care of prices and investment monitoring. Moreover, the responsibility of OFAS shall also include regulation of technical innovations in the industry, as well as monitoring of investments made in the basic stock (in the context of control over merging stocks and takeover of companies), and the Krasnoyarsk Patent Support Agency may provide some assistance in controlling the patent barriers in developing the competitive ability of the local food market.

\section{Competitive position development}

In our opinion, food market competitive position development implies the following priority measures:

\section{Boosting food products export to} neighbouring regions and states, despite the modest prospects of food provision of the region, carries the main strategic objective of the market development: at the initial stage, import phase-out technologies shall protect the local production, prospects and guarantees of the market outlet and economy within the scope of the market; however, without export-orientation of trade and inclusion of the food sector of the economy into the worldwide competition, there are all reasons for deceleration and further stagnation of the closed economy producing unsold goods. The existing export commodity structure (Table 1) may not be recognized as satisfactory in the context of stable development of favourable economic territory.

With the amount of food products export of 12.7 million USD, in the context of reviewing current relations with the food product supplier countries, the volume of import in the year 2014 exceeds the supply volume by four times (61.9 million USD0. For this reason, we believe that, taking the demographic characteristics into account, it is reasonable to support export-import trading relations with the CIS, APR countries, and China, the market capacity of which exceeds that of the domestic indicators by dozens of times.

2. Entering and consolidating the stand in the external food markets as a regulating measure are tightly connected with the previous

Table 1. Export commodity structure of the Krasnoyarsk Territory (Krai) in the years 2011-2014 (million USD), [1]

\begin{tabular}{|l|c|c|c|c|}
\hline \multicolumn{1}{|c|}{ Export structure } & \multicolumn{4}{c|}{ years } \\
\cline { 2 - 5 } & 2011 & 2012 & 2013 & 2014 \\
\hline Export, total & 9392.4 & 8315.9 & 787.2 & 7731.0 \\
\hline $\begin{array}{l}\text { including: food products and agricultural raw material } \\
\text { (except for textile) }\end{array}$ & 9.2 & 11.9 & 9.3 & $12.7^{2)}$ \\
\hline $\begin{array}{l}\text { Import, total } \\
\text { including: food products and agricultural raw material } \\
\text { (except for textile) }\end{array}$ & 33.6 & 50.9 & 77.6 & $61.9^{2)}$ \\
\hline
\end{tabular}


line of evolution of the Krasnoyarsk Territory (Krai) competitive position which, together with the others, shall make its contribution into the differentiated development of adjacent branches. A real competitive advantage for consolidating the stand of the food market is grocery trade, which, together with extracting and chemical industry, is the most promising economic driver at the present moment. To actualize the trading potential by means of grocery trade of the Krasnoyarsk Territory (Krai), it is required to target at the external markets by means of:

- simplification of export and import tariff system for the CIS and APR countries, including VAT recovery;

- providing non-discriminating access to the logistic export-import infrastructure to all economic agents of the trading sphere;

- ensuring advantageous business regime for the partner states where the Ministry of Industry, Energy and Trade and the Ministry of Agriculture shall act as intermediaries and guarantors in concluding partnership contracts;

- improving investor rights in the context of decreasing the risks for getting over the entrance and exit barriers of markets;

- regulation of protection of domestic manufacturers by foreign states by means of concluding partnership contracts and implementing tariff benefits;

- providing targeted financial aid for local manufacturers, also making an emphasis on small family business development, smoothening of the corruption component and optimization of control over the aid provided to such entrepreneurs.

\section{Achievement of food market stability in the} macroregional scale is mostly determined and associated with the general economic situation and state policy, which makes regional food market support measures a more topical issue. Regulating effect shall be targeted at decreasing the negative influence of all branches connected to the food market by means of: providing assistance to food market trading infrastructure; creating conditions for distributing products by the agricultural enterprises and product manufacturers themselves; increasing food product supply volume by improving farm capacities and creating adequate delivery and storage infrastructure; increasing food product manufacturing margin by implementation of technological innovations [3].

4. Ensuring optimal food consumption by various strata of the regional society is closely connected to the measures taken for maintaining social stability in the Krasnoyarsk Territory (Krai). Physical and economic availability of food products are connected both to the stabilization of income for all strata of the society and the opportunity of getting well-balanced eco-friendly foods in the present and the future. The major part of such regulation includes financial support of the poor, provision of well-balanced meals to pre-school and school students, implementation of resource-saving technologies and food waste processing technologies for the agricultural needs, exclusive use of healthy local and wildgrowing crops for food production [6].

\section{Competitive status development}

Competitive status development, being a cumulative effect of the corrective actions it consists of, separately includes a set of measures for:

- Information and communication medium development. In the past two decades, a significant feature of the modern society has been stereotypical thinking and consumerist ideology, creating breeding grounds for the excessive attention of manufacturers and suppliers to marketing tools in creating massive consumerist culture, transforming cultural values into endless consumption, where it is not the product that matters, but the consumption process itself. 
For this reason, we consider it necessary to concentrate the competitive status development on the following suggestions:

1) Start mass media propaganda of healthy lifestyle, including well-balanced nutrition, sports, environment protection and avoidance of overeating, physical inactivity and bad habits.

2) Create public catering facilities specializing on healthy nutrition, systematic nutrition, medical diets and reducing the number of fast food catering facilities.

4) Start cooperation between regional authorities and mass media in order to produce a cycle of programmes dedicated to inspection of service industry facilities.

5) Constant cooperation of Krasnoyarsk Centre for Standardization and Metrology with mass media to convey information on food products quality checks and eco-friendly healthy production technologies to the public.

6) Promoting regional legislative acts limiting the "take-it-or-leave-it" tone of food products advertising, reducing the manipulating role of advertising.

7) Development and promotion of a healthy nutrition programme for school and college students, including grants for healthy nutrition of school students.

8) Organization of free meals for the poor living in the territory of the region.

- Re-orientation of individual branding to branding technologies for categories of goods. Occupying more and more space in the modern life and acting as a measure of one's position on the scale of social and economic success, brands considerably increase financial load on the cost of food products produced of the same material and with the same technologies as generic ones. For this reason, it is suggested to review the option of reducing price load on the consumer on the regional level, by means of creating a single regional umbrella brand and developing a unified system of its promotion supported by regional authorities. Such umbrella brand of food products may act as a partial substitution of individual brands, like single brands of distribution chains, and solve the task of reducing the cost of goods, the brand signature including its package, promotion, advertising, thereby shifting the marketing measures from competition of individual brands to the competition of technologies, stimulating the formation of a single comfortable medium of consumption of products of guaranteed high quality.

- Increasing awareness and legal literateness of the population, which, being one of the civilization achievements, acts as a criterion of an individual's ability of solving sophisticated social and economic problems, as a criterion of one's civil freedom. Ignorance of consumer rights and inability of protecting them at a court, elementary legal ignorance and misunderstanding of authority hierarchy from the legal communication point of view, complicated legislation process generate ideology of a legally weak state with the corresponding competitive status, indifferent to the lives of its citizens. Development of the spiritual and moral component of social life by means of legal education includes the current questions of developing the sense of need for adequate consumer behaviour, education of morality and reasonable consumer behaviour along with care to the environment and natural resources.

- Creation and support of the regional image as a socially responsible business partner. Within this measure, it is suggested to concentrate on the propaganda methods of forming and supporting the competitive status of the Krasnoyarsk Territory (Krai) food market for its consumers, by means of:

A) developing regional consumer support institutions through the system of information and consultative services, information centres 
at the Krasnoyarsk Society of Consumer Rights'

Protection, Krasnoyarsk Centre for Standardization and Metrology, Krasnoyarsk OFAS etc.;

B) regional authorities' support of the institution structure of the civil society, development of self-administration, involvement of the public into the discussions of current food market problems in the context of solving present social and economic issues.

From the suppliers' point of view, the image of the food market as a socially responsible partner shall be formed with the whole range of classic tools for business support used to reduce the market barriers and the measures guaranteeing the stability of demand and consumption within the territory, supporting payment capacity of the population.

Therefore, the suggested lines of development help considering the peculiarities of the food market as a part of service industry and solving the issues of increasing social and economic wealth of the local citizens.

\section{References}

http://krasstat.gks.ru/

Shastitko, A.E. (2010) Sopostavimost' rynkov v kontekste antimonopol'nogo regulirovaniia [Comparativeness of Markets in the Antimonopoly Regulation Context] / A.E. Shastitko, In Ekonomicheskaiia politika [Economic Policy], (1), p. 98-105.

Shcherbenko, E.V. (2008) Tselevye parametry razvitiia otrasley pishchevoy promyshlennosti [Target Development Parameters for the Food Industry Branches] / E.V. Shcherbenko, In Segodnia $i$ zavtra rossiyskoy ekonomiki [Today and Tomorrow of Russian Economy], (21), p. 116-122.

Iushkova, L.V. (2013) Metod konkurentnykh kart v obosnovanii konkurentnogo statusa prodovol'stvennogo rynka [Competition Mapping Method of Justifying the Competitive Status of the Food Market] / L.V. Iushkova, In Nauchnoe obozrenie. Seriia 1: Ekonomika i pravo [Scientific Review. Series 1: Economics and Law], (6), p. 35-41.

Iushkova, L.V.(2007) Prioritetnye instrumentyotsenkiotraslevoy konkurentnoy sredy vishchevoy promyshlennosti [Priority Evaluation Tools for the Competitive Environment of Food Industry] / L.V. Iushkova, In Problemy sovremennoy ekonomiki [Modern Economic Problems], (4), p. 121-126.

Iakimova, E.A. (2015) Problemy povysheniia konkuretosposobnosti produtsii traditsionnykh promyslov malochislennykh narodov Kraynego Severa [Problems of Increasing Competitive Ability of Traditional Products of the Small-Numbered Peoples of the Extreme North] / E.A. Iakimova, V.V. Vingert, O.V. Ryzhikova, In: Ekonomika i predprinimatel'stvo [Economics and Entrepreneurship], (10-2) (63-2), p. 409-412. 


\section{Приоритетные направления развития \\ конкурентного статуса \\ продовольственного рынка \\ Красноярского края}

Ю.Л. Александров, Л.В. Юшкова

Сибирский федеральный университет Россия, 660041, Красноярск, пр. Свободный, 79

В статье приводятся основные направления развития конкурентного статуса продовольственного рынка Красноярского края. Показано, что его развитие зависит от достижения условий открытой конкурентной среды, создающей равныле условия для всех участников, повышения конкурентоспособности продовольственного рынка и его товаров, применения технологических инноваций, усиления конкурентной позиции продовольственного рынка Красноярского края в СФО и на внешних рынках. Отдельное направление связано с формированием информационно-коммуникационного пространства как связующей силь в создании и поддержании имиджа продовольственного рынка Красноярского края - надежного, сочиально-ответственного и стабильного бизнес-партнера.

Ключевые слова: продовольственный рынок, конкурентный статус, конкурентоспособность, конкурентная позиция.

Научная специальность: 08.00.00 - экономические науки. 